\title{
Tradisi Perkawinan Kerubuhan Gunung dalam Pandangan Tokoh Masyarakat
}

\author{
Lailatus Sumarlin \\ Fakultas Syariah UIN Maulana Malik Ibrahim Malang \\ sumarlin@yahoo.co.id
}

\begin{abstract}
:
This article aims to describe the views of community leaders Kepanjen District of Malang on mountain kerubuhan tradition and its relevance to Islamic marriage laws. Kerubuhan mountain tradition of marriage does not allow a person to get married when there are close relatives who died. For those who violate this tradition is given a moral sanction as it gets gossip. Implementation tradition closely associated with local knowledge of local communities. In the tradition of mountain kerubuhan, although Islam does not regulate the implementation of this tradition, there is the implied meaning is to be found, namely curb suppress personal ego, mutual respect, respect, and foster tolerance among fellow with'm sorry for the death of a close relative.

Artikel ini bertujuan mendeskripsikan pandangan tokoh masyarakat Kecamatan Kepanjen Kabupaten Malang tentang tradisi kerubuhan gunung dan relevansinya dengan hukum perkawinan Islam. Tradisi perkawinan kerubuhan gunung tidak memperbolehkan seseorang untuk melangsungkan pernikahan ketika terdapat keluarga dekat yang meninggal dunia. Bagi mereka yang melanggar tradisi ini diberikan sanksi moral seperti mendapat gunjingan. Pelaksanaan tradisi berkaitan erat dengan kearifan lokal masyarakat setempat. Dalam tradisi kerubuhan gunung, meskipun ajaran Islam tidak mengatur pelaksanaan tradisi ini, ada makna tersirat yang dapat ditemukan yaitu mengekang menekan ego pribadi, saling menghormati, menghargai, dan menumbuhkan sikap toleransi antar sesama dengan ikut berduka atas kematian saudara dekatnya.
\end{abstract}

Kata Kunci: Kerubuhan Gunung; Perkawinan; Tradisi

\section{Pendahuluan}

Manusia diciptakan Allah SWT. secara berpasang-pasangan, laki-laki dan perempuan. ${ }^{1}$ Hal ini bertujuan agar mereka dapat menghasilkan keturunan ${ }^{2}$ dan kehidupan di alam semesta berkesinambungan dari generasi ke generasi. ${ }^{3}$ Untuk menyalurkan hasrat berpasang-pasangan ini, Allah SWT. memberikan sarana berupa lembaga perkawinan. Secara yuridis, perkawinan merupakan ikatan lahir batin seorang pria dengan seorang wanita sebagai suami istri dengan tujuan membentuk keluarga yang bahagia dan kekal berdasarkan Ketuhanan Yang Maha Esa. ${ }^{4}$ Keluarga merupakan masyarakat yang paling kecil dan dihuni oleh suami, istri dan anak-anak. Keluarga menjadi tempat bagi anggotanya untuk memenuhi berbagai kebutuhan, baik fisik,

\footnotetext{
${ }^{1}$ Q.S. Adz-Dzaariyat [51]: 49

${ }^{2}$ Siti Romlah, Karakteristik Keluarga Sakinah Dalam Perspektif Islam Dan Pendidikan Umum (Jakarta: UII Press, 2006), 67.

${ }^{3}$ M. Ali Hasan, Pedoman Hidup Berumah Tangga Dalam Islam (Jakarta: Prenada Media Group, 2006$), 1$.

${ }^{4}$ Undang-Undang Nomor 1 Tahun 1974 tentang Perkawinan LN. Tahun 1974 No. 1

Jurisdictie: Jurnal Hukum dan Syariah Vol. 6 No. 1 Tahun 2015
} 
psikologis, religius, edukatif, rekreatif, maupun ekonomi..$^{5}$ Tidak hanya itu, keluarga yang harmonis dan sejahtera merupakan salah satu sendi utama dalam kehidupan bermasyarakat. Secara umum, kehidupan berkeluarga terikat oleh serangkaian norma yang hidup dan berkembang dimasyarakat. Norma-norma yang terus dilestarikan berkembang menjadi sebuah tradisi. Dalam tradisi masyarakat Jawa misalnya, perkawinan bukan hanya sekedar ijab dan qabul antara calon mempelai laki-laki dan wali calon mempelai perempuan. Ikatan perkawinan didahului oleh serangkaian acara mulai dari tahapan tembungan, yaitu pembicaraan khusus antara keluarga kedua calon mempelai terkait status, kesediaan serta kesepakatan tentang perkawinan. Tahapan selanjutnya yaitu nglamar atau peminangan, yang biasa disertai dengan acara liru kalpika rukmi (tukar cincin) sebagai tanda pacangan (perjodohan). Tujuh hari atau lima hari (sepasar) sebelum pelaksanaan perkawinan, biasanya diadakan kumbakarnan atau rapat keluarga terkait pelaksanaan perkawinan. Acara ini diadakan di rumah keluarga yang akan menyelenggarakan hajatan dengan mengundang para sesepuh, tokoh masyarakat, keluarga dan tetangga terdekat. Tiga hari sebelum pelaksanaan hajatan perkawinan, diadakan berbagai kegiatan, yakni pasang tarub yaitu mempersiapkan tempat dilaksanakannya acara hajatan perkawinan secara keseluruhan, baik diadakan di gedung ataupun di rumah sendiri, siraman untuk calon pengantin perempuan dan disesuaikan dengan hari kelahirannya, di-paes pada bagian rambut pada dahi dan kening disungging dengan warna hitam sebagai tanda siap melaksanakan perkawinan dan secara mental siap menjadi ibu rumah tangga, sengkeran atau pingitan yaitu calon pengantin perempuan yang sudah melakukan ritual siraman sudah tidak diperbolehkan keluar dari area rumah, sampai saat pelaksanaan perkawinan, midodareni dan majemukan dilaksanakan pada malam menjelang dilaksanakannya perkawinan dengan menghadirkan para sesepuh. ${ }^{6}$

Tradisi seperti ini di beberapa wilayah masih dipegang teguh dan bernilai sakral. Salah satunya adalah tradisi kerubuhan gunung yang dilestaikan oleh masyarakat Kabupaten Malang. Kerubuhan Gunung memiliki arti wong nemoni kesusahan sing gedhé banget. ${ }^{7}$ Rencana perkawinan yang sudah disiapkan sedemikian rupa terpaksa ditunda untuk menghindari bala'. Peristiwa seperti ini tidak jarang menimpa sejumlah calon pasangan suami-istri di wilayah Kecamatan Kepanjen Kabupaten Malang. Berbagai tradisi yang hidup dan berkembang di masyarakat masih menarik minat banyak akademisi untuk melakukan kajian. Misalnya Tradisi Kaboro Co'i Pada Perkawinan Masyarakat Bima Perspekti Urf Di Kecamatan Monta Kabupaten Bima, ${ }^{8}$ Tradisi Begalan Dalam Perkawinan Adat Banyumas Perspektif 'Urf', ${ }^{9}$ Tradisi Kawin Boyong Dalam Perkawinan Adat Masyarakat Gesikan, ${ }^{10}$ Tradisi Penyerahan Perabot Rumah Tangga Dalam Perkawinan, ${ }^{11}$ Dan Pandangan Masyarakat Terhadap Tradisi Ngelangkahi Pasangan Sapi Dalam Prosesi Perkawinan Di Desa Kepuh

\footnotetext{
${ }^{5}$ Romlah, Karakteristik Keluarga Sakinah, 67.

${ }^{6}$ Muhammad Sholikhin, Ritual Dan Tradisi Islam Jawa: Ritual-Ritual Dan Tradisi-Tradisi Tentang Kehamilan, Kelahiran, Pernikahan, Dan Kematian Dalam Kehidupan Sehari-Hari Masyarakat Islam Jawa (Yogyakarta: Narasi, 2010), 202-5.

${ }^{7}$ KS, Wawancara (Malang: 2 Januari 2015)

${ }^{8}$ Suharti Suharti, "Tradisi Kaboro Co'i pada perkawinan masyarakat bima perspektif urf di Kecamatan Monta Kabupaten Bima" (undergraduate, Universitas Islam Negeri Maulana Malik Ibrahim, 2008), http://etheses.uinmalang.ac.id/4287/.

${ }^{9}$ Arini Rufaida, "Tradisi begalan dalam perkawinan adat Banyumas perspektif 'urf" (undergraduate, Universitas Islam Negeri Maulana Malik Ibrahim, 2011), http://etheses.uin-malang.ac.id/1420/.

${ }^{10}$ Moh Mus'id Adnan, "Tradisi kawin boyong dalam perkawinan adat masyarakat Gesikan: Studi kasus di Desa Gesikan Kec.Grabagan Kab.Tuban" (undergraduate, Universitas Islam Negeri Maulana Malik Ibrahim, 2008), http://etheses.uin-malang.ac.id/4226/.

${ }^{11}$ Maullimatul Athiyah, "Tradisi penyerahan perabot rumah tangga dalam perkawinan: Studi Kasus di Desa Karduluk Kec. Pragaan Kab. Sumenep Madura” (undergraduate, Universitas Islam Negeri Maulana Malik Ibrahim Malang, 2010), http://etheses.uin-malang.ac.id/1457/.
} 
Kecamatan Papar Kabupaten Kediri. ${ }^{12}$ Meskipun demikian, belum ada yang melakukan eksplorasi terhadap fenomena tradisi kerubuhan gunung di masyarakat Kabupaten Malang. Artikel ini bertujuan mendeskripsikan pandangan tokoh masyarakat Kecamatan Kepanjen Kabupaten Malang terhadap tradisi perkawinan kerubuhan gunung dan mengetahui relevansinya dengan perkembangan hukum perkawinan Islam.

\section{Metode Penelitian}

Penelitian ini termasuk dalam penelitian empiris, karena lokus penelitian berada di wilayah Kecamatan Kepanjen Kabupaten Malang. ${ }^{13}$ Penelitian ini menggunakan data kualitatif sebagai bahan utamanya. Data primer dalam penelitian diperoleh melalui proses wawancara dengan informan, yaitu tokoh masyarakat di Kecamatan Kepanjen Kabupaten Malang. ${ }^{14}$ Data sekunder berupa buku-buku tentang tradisi masyarakat Jawa dan buku tentang perkawinan. ${ }^{15}$ Selain itu, penelitian ini juga menggunakan sumber data tersier berupa kamus. Penelitian ini menggunakan pendekatan fenomenologi untuk melihat secara dekat interpretasi informan tentang tradisi kerubuhan gunung di wilayah Kecamatan Kepanjen Kabupaten Malang. Peneliti berusaha memahami pengalaman dari perspektif para informan. Di dalam pendekatan ini juga diajarkan untuk memahami bahwa pengalaman seseorang dengan yang lainnya adalah bervariasi dan kompleks. ${ }^{16}$

\section{Hasil dan Pembahasan}

\section{Pandangan Tokoh Masyarakat terhadap Tradisi Perkawinan Kerubuhan Gunung}

Secara etimologis tradisi merupakan kebiasaan yang dilakukan secara turun temurun. ${ }^{17}$ Istilah tradisi secara umum dimaksudkan untuk menunjuk kepada suatu nilai, norma dan adat kebiasaan yang lama dan hingga kini masih diterima, diikuti bahkan dipertahankan oleh kelompok masyarakat tertentu. ${ }^{18}$

Berkaitan dengan makna tradisi, informan penelitan sepakat bahwa adalah sesuatu yang dilakukan berulang kali dan keberadaannya sudah ada sejak zaman dahulu. Tradisi dibawa oleh nenek moyang/leluhur dan diteruskan kepada generasi yang saat ini masih hidup. Sebagaimana disampaikan oleh $\mathrm{AB}^{19}$ dan $\mathrm{SL}^{20}$. Menurut $\mathrm{MB}^{21}$ tradisi merupakan satu kebiasaan yang ada dan telah lama berkembang di masyarakat. Keyakinan akan tradisi pada akhirnya membentuk sebuah pola perilaku dalam masyarakat yang terwujud pada etika maupun perilaku. Tradisi memiliki berbagai fungsi di masyarakat, antara lain: 1) Sebagai wadah ekspresi keagamaan bagi masyarakat yang bersifat baku, tertentu, dan tidak bisa diubah-ubah.; 2) Sebagai alat pengikat kelompok untuk mempertahankan keharmonisan dan ketentaraman hidup bermasyarakat; 3) Sebagai benteng pertahanan kelompok terhadap

\footnotetext{
12 Siti Rodliyah, "Pandangan masyarakat terhadap tradisi ngelangkahi pasangan sapi dalam prosesi perkawinan di Desa Kepuh Kecamatan Papar Kabupaten Kediri” (undergraduate, Universitas Islam Negeri Maulana Malik Ibrahim, 2010), http://etheses.uin-malang.ac.id/1711/.

${ }^{13}$ Mardalis, Metode Penelitian Suatu Pendekatan Proposal (Jakarta: Bumi Aksara, 1999), 28.

${ }^{14}$ Marzuki, Metodologi Riset (Yogyakarta: PT. Prasetia Widia Pratama, 2000), 55.

${ }^{15}$ Soejono Soekanto, Pengantar Penelitian Hukum (Jakarta: UI Press, 1986), 12.

${ }^{16}$ Emzir, Analisis Data: Metodologi Penelitian Kualitatif (Jakarta: RaJawali Pres, 2010), 22.

${ }^{17}$ Pius A. Partanto and M. Dahlan Al Barry, Kamus Ilmiah Populer (Surabaya: Arloka, 1994), 756.

18 Soenarto Timoer, Mitos Çūra-Bhaya: Cerita Rakyat Sebagai Sumber Penelitian Sejarah Surabaya (Balai Pustaka, 1983), 11.

${ }^{19}$ AB, Wawancara (Malang, 2 Januari 2015)

${ }^{20}$ SL, Wawancara (Malang, 2 Januari 2015)

${ }^{21} \mathrm{MB}$, Wawancara (Malang, 2 Januari 2015)
} 
budaya luar atau perkembangan zaman. ${ }^{22}$ Tradisi yang ada dalam masyarakat dapat berkembang dan diwariskan dari generasi ke generasi. Pewarisan tradisi tidak terjadi secara pasif, tetapi juga dikonstruksi sesuai dengan yang dipahami oleh ahli waris dalam konteks sosial budaya di mana mereka berada. ${ }^{23}$ Terkait dengan tradisi kerubuhan gunung, SY salah seorang tokoh agama menyatakan bahwa:

Kerubuhan gunung niku mewawi wonten tiyang ingkang bade nikah lajeng tiang sepahipun wonteng ingkang pejah, lajeng akad nikah dipun tunda tahun ngajeng. Menawi ninggale pas wulan suro, nggeh calon pengantin nembe saget nikah wekdal wulan suro tahun ngajeng. Nek pejahe pas wulan besar, berarti nikahe nggeh diundur sampek wulan besar ngajeng. Kerubuhan gunung niku warisan adat, menawi niatipun hormat leluhur nggeh mboten nopo-nopo. Tetapi catatannya nggeh tetep harus tawakkal dateng gusti Allah SWT. ${ }^{24}$

Sedangkan menurut SR istilah kerubuhan gunung memiliki definisi sebagai berikut:

Istilah kerubuhan gunung muncul karena ada seseorang yang terkena musibah. Ada yang meninggal keluarganya. Maka perkawinan yang sudah direncanakn harus ditunda terlebih dahulu pelaksanaannya. Wong ya namanya tradisi. Itu bawa'ane leluhur yang katanya membawa dampak besar jika tidak dilaksanakan. itu karena banyak yang sudah merasakan dampaknya jika tidak mengikuti apa yang dikatakan para leluhur terdahulu. ${ }^{25}$

Sependapat dengan pandangan informan di atas, SL memberikan definisi serupa tentang tradisi kerubuhan gunung. Namun, SL memberikan tambahan sebagai berikut:

Jika ada salah satu anggota keluarga yang meninggal dunia, seseorang dituntut untuk berempati terhadap kesedihan yang dirasakan oleh orang lain. Tidak baik jika tetap menggelar perkawinan sementara keluarga besar kita ada yang meninggal dunia. Ada sebagian orang melakukan akad nikah disamping mayit, ada juga yang mundur satu tahun. ${ }^{26}$

Berdasarkan informasi yang disampaikan SL selaku tokoh agama di wilayah Kecamatan Kapanjen Kabupaten Malang, diketahui bahwa telah ada pergeseran perilaku masyarakat dalam menanggapi tradisi kerubuhan gunung. Ada sebagian yang memilih menunda dilaksanakannya perkawinan dan ada pula yang memilih melaksanakan perkawinan disamping jenazah atau dikenal dengan kawin mayit. Terkait dengan penundaan perkawinan dalam tradisi kerubuhan gunung, BT salah satu tokoh agama menyatakan sebagai berikut:

Dalam ajaran islam penundaan dengan alasan seperti ini gak ada. Jelas gak sesuai dengan syariat. Tapi masyarakat itu kadang-kadang merasa gak enak. Jika dilanggar mereka merasa takut jadi bahan omongan orang lain, nggak kuat mentalnya. ${ }^{27}$

Tradisi memiliki fungsi sebagai pedoman kehidupan bermasyarakat. Dalam sebuah tradisi terkandung berbagai makna dan norma yang mengikat masyarakat. Norma-norma itu

\footnotetext{
${ }^{22}$ Imam Bawani, Tradisionalisme Dalam Pendidikan Islam: Studi Tentang Daya Tahan Pesantren Tradisional (Surabaya: Al-Ikhlas, 1993), 34-35.

${ }^{23}$ Ahmad Khalil, Islam Jawa: Sufisme Dalam Etika Dan Tradisi Jawa (Malang: UIN-Malang Press, 2008), VIIIX.

${ }^{24}$ Sy, Wawancara (Malang, 6 Februari 2015)

${ }^{25}$ SR, Wawancara (Malang, 6 Februari 2015)

${ }^{26}$ SL, Wawancara (Malang, 2 Januari 2015)

${ }^{27}$ BT, Wawancara (Malang, 6 Februari 2015)
} 
mempunyai kekuatan mengikat dan anggota masyarakat pada umumnya tidak berani untuk melanggarnya. ${ }^{28}$ Bagi masyarakat Jawa misalnya, melaksanakan tradisi nenek moyang mengajak seseorang untuk menjadi bijaksana, sadar akan posisi serta tata cara dalam pergaulan dimasyarakat. Masyarakat Jawa menjunjung tinggi etika dengan cara menyampaikan sesuatu secara patut. Menunda acara perkawinan dalam tradisi kerubuhan gunung sebagaimana disampaikan oleh informan di atas, bagian ekspresi dari duka cita mendalam terhadap meninggalnya anggota keluarga, khususnya orang tua. Pelaksanaan tradisi kerubuhan gunung, sebagaimana tradisi-tradisi yang ada pada masyarakat Jawa bertujuan terjaga dan terpeliharanya kondisi yang harmonis dalam keluarga. Masing-masing orang dituntut mampu menguasai diri, tidak terbawa hawa nafsu, menghindari pertikaian dan perselisihan. Selain itu, nilai-nilai tradisi yang dibangun pada masyarakat Jawa bertujuan memunculkan semangat hidup serta menanamkan rasa kepedulian dan saling tolong menolong antar sesama. ${ }^{29}$

Tradisi, termasuk tradisi kerubuhan gunung hidup dan berkembang dimasyarakat Kecamatan Kepanjen Kabupaten Malang melalui dua cara, yaitu secara spontan dan dipaksakan oleh mereka yang memiliki otoritas. ${ }^{30}$ Salah satu alat paksa sebuah tradisi adalah sanksi adat. Menurut AB salah satu sanksi yang diberikan sebagai berikut:

Sanksi seng bakal dirasakne mbek uwong seng gak nglakoni tradisi biasane dadi rasan-rasan tonggo liyane. Pokoke ndek pandangane wong kampung wes gak patuh ambek tradisi seng onok ndek kunu. Malah tau enek kejadian uwong kang gak nglakoni tradisi, mbek tonggo-tonggo liyane gak disraungi. Dijarne sak karepe. Pokok nek kape jalok tolong gak usah ditulungi. ${ }^{31}$

Sementara itu SL menyampaikan pendapat yang berbeda, bahwa tidak melaksanakan tradisi tidak membawa dampak apa-apa terhadap pelaku. Lebih lanjut SL menyatakan sebagai berikut:

Saya kira tidak ada dampak jika tidak melakukan tradisi ini. Jika perkawinannya ditunda biasanya hal itu merupakan permintaan keluarga. Dampak kemasyarakat secara langsungjuga tidak ada. Tetapi ada juga yang tetap melaksanakan perkawinan karena tanggal sudah ditentukan dan dengan alasan tertentu tidak bisa mundur, misalnya si wanita sudah hamil duluan, pergi jauh dari rumah karena belajar atau bekerja.. Makanya harus segera diadakan pernikahan. ${ }^{32}$

Meskipun tidak ada sanksi hukum terhadap anggota masyarakat yang tidak melaksanakan tradisi perkawinan kerubuhan gunung, $\mathrm{AB}$ menyatakan bahwa:

Hidup ditengah-tengah masyarakat pada prinsipnya harus menghargai tradisi, tidak bisa semaunya sendiri. Bagi mereka yang tidak mau melakukan tradisi ya tidak apa-apa karena tidak ada sanksi hukumnya. Hanya saja mereka jadi bahan rasan-rasan atau dapat komentar negatif dari tetangga satu kampung

Sanksi sosial yang diberikan kepada mereka yang berani melanggar tradisi, membuat tradisi perkawinan kerubuhan gunung masih eksis di wilayah Kecamatan Kepanjen kabupaten Malang. Sebagaimana informasi yang disampaikan oleh RY:

Biasanya, sangat jarang sekali orang yang tetap melakukan pernikahan jika ada keluarga yang meninggal dunia. Karena adanya sikap toleransi yang tinggi oleh

\footnotetext{
${ }^{28}$ Abu Ahmadi, Ilmu Sosial Dasar (Jakarta: Bina Aksara, 1988), 56.

${ }^{29}$ Khalil, Islam Jawa, 20-21.

${ }^{30}$ Piotr Sztompka, Sosiologi Perubahan Sosial (Jakarta: Prenada Media Group, 2007), 71-72.

${ }^{31} \mathrm{AB}$, Wawancara (Malang, 2 Januari 2015)

${ }^{32}$ SL, Wawancara (Malang, 2 Januari 2015)
}

Jurisdictie: Jurnal Hukum dan Syariah Vol. 6 No. 1 Tahun 2015 
penduduk sendiri. Para warga bisa dikatakan sangat jarang yang melanggar wasiat dari para sesepuh. Mereka yakin akan informasi yang disampaikan sesepuh meskipuni dalam ajaran agama tidak. Antara nikah dan kematian seseorang tiadalah hubungannya. ${ }^{33}$

Sedangkan menurut MB penghormatan terhadap tradisi dan mengedepankan sikap toleransi urgen dilaksakan dalam kehidupan bermasyarakat. Tradisi perkawinan kerubuhan gunung dianggap masyarakat Kecamatan Kepanjen Kabupaten Malang sebagai alat pengikat kelompok untuk mempertahankan keharmonisan dan ketentaraman hidup bermasyarakat, khususnya di lingkungan keluarga. ${ }^{34}$ Lebih lanjut MB menyatakan bahwa:

Melaksanakan pernikahan ketika ada keluarga dekat yang meninggal itu tidak etis. Seperti tidak menghormati yang meninggal. Ada waktu untuk berkabung, jika meninggalnya pada saat acara pernikahan berlangsung, dan tidak bisa ditunda maka perkawinan tetap dilangsungkan tapi biasanya sound system-nya dimatikan, untuk menghormati..$^{35}$

Berdasarkan pandangan informan di atas, merupakan suatu ketidakpatutan seseorang saat yang lain merasa kesusahan, tetapi tetap saja melakukan hal-hal yang menggambarkan kebahagiaan, seperti resepsi pernikahan. Penundaan hingga tahun depan adalah jalan terbaik yang bisa ditempuh. Lain lagi jika memang waktu dilangsungkannya pernikahan, terdapat orang tua yang meninggal. Maka bentuk duka kita bisa diungkapkan dengan mematikan sound system yang ada. Dengan demikian, dapat disimpulkan bahwa jika akan dilangsungkan pernikahan dan terdapat salah satu orang tua atau keluarga garis ke atas meninggal dunia, maka pernikahan tersebut harus ditunda hingga tahun depan atau bisa juga dilaksanakan perkawinan tersebut bersamaan dengan adanya si mayit. Alasan kuat yang mendasari untuk menunda perkawinan tersebut hingga tahun depan yakni hormat kepada si mayit. Menandakan bahwa pada masa itu adalah masa berduka dan tidak harus disandingkan dengan perkawinan yang sejatinya adalah sebuah kebahagiaan.

Berdasarkan informasi para tokoh adat, tokoh agama, dan tokoh pemerintahan di wilayah Kecamatan Kepanjen Kabupaten Malang tidak terdapat sanksi berat yang diberikan masyarakat terhadap orang yang tidak patuh terhadap tradisi perkawinan kerubuhan gunung. Hanya saja terdapat beberapa hal yang harus dipertimbangkan seseorang jika mengambil sikap terhadap tradisi ini. Sikap toleransi antara sesama dalam hal ini juga menjadi perhatian penting akan penentuan dua pilihan jika mendapati kejadian, di mana salah satu orang tua atau kerabat lurus ke atas ada yang meninggal dunia. Pada sisi yang lain, disebutkan bahwa antara nikah dan meninggal, masing-masing memiliki posisi yang berbeda. Keduanya tidak saling berhubungan dan tidak memiliki kesamaan posisi. Meninggal dan perkawinan adalah dua halyang berbeda dan tidak bisa saling mempengaruhi. Jadi, jika tradisi kerubuhan gunung dihubungkan dengan meninggalnya seseorang, maka sejatinya tidak sesuai. Tetapi, berhubung yang meninggal dunia disini adalah orang yang punya hajat (perkawinan) itu sendiri ataupun masih terdapat hubungan kerabat dengan yang punya hajat, alan utama yang harus ditempuh yakni menunda hingga tahun depan. Di samping menghindari cemoohan masyarakat sekitar, hal ini juga merupakan langkah untuk memuliakan dan menghormati keluarga yang sedang dilanda duka. Seperti yang sudah dibahas di atas, tradisi adalah suatu kebiasaan yang memang sudah mengakar dalam suatu kehidupan bermsyarakat. Ketentuan tradisi itu sendiri, sanksi yang ditimbulkannya adalah hal melekat yang tidak bisa terpisahkan oleh orang Jawa pada

${ }^{33} \mathrm{RY}$, Wawancara (Malang, 2 Januari 2015)

${ }^{34}$ Bawani, Tradisionalisme Dalam Pendidikan Islam, 34-35.

${ }^{35} \mathrm{MB}$, Wawancara (Malang, 6 Januari 2015) 
umumnya. Kepercayaan akan timbulnya sesuatu berbahaya jika tidak menaati perkataan orang terdahulu juga kerap dihubungkan dengan adanya sanksi dari suatu perbuatan melanggar tradisi. Seperti halnya pernyataan yang diungkapkan oleh RY:

Secara tidak langsung tradisi yang telah berkembang di dalam masyarakat wilayah Kecamatan Kepanjen ini memang sudah diyakini kebenarannya karena memang memiliki beberapa makna, seperti menumbuhkan sikap toleransi antar satu dengan yang lain. Menawi gak enek sikap toleransi, ya hidup sendirian di lingkungan masyarakat. Dan sejauh ini memang tidak terdapat orang yang keberatan tentang pelaksanaan tradisi ini, karena memang telah terbukti kebenarannya oleh orang-orang yang tidak mematuhi petuah para leluhur. Seperti pernikahan yang seumur jagung, tidak bisa langgeng, adanya sanak saudara yang meninggal dengan waktu yang tak jauh dari waktu pernikahan tersebut. ${ }^{36}$

Sikap toleransi adalah salah satu bentuk makna yang tersirat dalam tradisi perkawinan kerubuhan gunung. Secara sederhana, tradisi ini menghendaki toleransi dalam tradisi ini ditumbuhkan dengan penundaan pernikahan dari rencana sebelumnya dan turut serta berduka atas meninggalnya sanak saudara. Toleransi juga digambarkan dengan tidak dilakukannya pernikahan hingga masa duka selesai dialami oleh keluarga terdekat kita. Hal ini bertujuan menjaga keharmonisan yang sangat ditekankan dalam tradisi masyarakat Jawa. Sanksi yang diberikan kepada palaku pun memiliki kekuataan mengikatnya sedang. Tidak sampai ada sanksi berarti yang diterima oleh masyarakat yang tidak melakukan tradisi ini. Hanya cemoohan dan gunjingan yang dirasakan oleh para pelaku.

\section{Tradisi Perkawinan Kerubuhan Gunung bagi Perkembangan Hukum Perkawinan Islam}

Tokoh agama, tokoh adat, dan tokoh pemerintahan yang menjadi informan memberikan jawaban yang berbeda terhadap relevansi tradisi perkawinan kerubuhan gunung bagi perkembangan hukum perkawinan Islam. Sebagaimana yang disampaikan oleh SY:

Menurut kulo tradisi kerubuhan gunung mboten wonten hubungane kalian akad nikah. Sebab niku persoalan adat yang tidak harus mengikat masyarakat. Hukumnya mboten wonten dalam Islam. Niku dipun lakoni kagem hormat leluhur. Hormat niku kan benten kaleh nyembah. Seandainya tiyang-tiyang mboten menggunakan nggeh mboten dados masalah. Seng luwih utama nek geblake wong tuwo, seng bener niku didungakne, shodaqoh. Lha lek geblake wong tuwo terus hura-hura iku malah seng gak tepak. Apike ncen diundur sampek tahun ngarep. Selain hormat pada si mayit, nggeh ben rumah tanggane lancar. mboten kebayang sedone tiyang sepah terus. Mosok nikah seumur hidup pisan harus dibarengne mbek kesusahan. Mending diundur senajan sembarange wes siap kabeh. Seng penting gak sampek menimbulkan gejolak di masyarakat. ${ }^{37}$

Hal senada juga diungkapkan oleh BT sebagai tokoh agama di wilayah Kecamatan Kepanjen Kabupaten Malang:

Yang jelas dalam syariat Islam tidak ada istilah kerubuhan gunung. Masyarakat itu kadang-kadang merasa tidak enak. Takut jika tidak melakukan dapat cemooh atau gunjingan orang banyak, dahulu masih banyak kejadian seperti ini. Tapi sekarang sudah mulai pudar. ${ }^{38}$

\footnotetext{
${ }^{36}$ RY, Wawancara (Malang, 2 Januari 2015)

${ }^{37}$ SY, Wawancara (Malang, 6 Februari 2015)

${ }^{38}$ BT, Wawancara (Malang, 6 Februari 2015)
} 
Berdasarkan informasi di atas, Jelas tidak ada dalil yang mengatur tentang tradisi perkawinan ini. Tradisi perkawinan kerubuhan gunung merupakan simbol menghormati para leluhur. Dampak-dampak negatif yang ditimbulkan nantinya hanya mitos belaka, yang memang terkadang terbukti kebenarannya, tetapi tidak boleh dijadikan suatu keyakinan tetap untuk mengikuti segala yang diajarkan. Penundaan yang dilakukan berkaitan dengan keyakinan masyarakat Jawa yang menganggap pernikahan sebagai sesuatu yang sakral, sehingga diharapkan dalam menjalaninya cukup sekali dalam seumur hidup, didasarkan pada proses yang selektif dan hati-hati baik saat pemilihan calon menantu ataupun penentuan saat yang tepat bagi terlaksananya perkawinan tersebut. ${ }^{39}$ Menurut $\mathrm{AB}$, tradisi yang diturunkan dari generasi terdahulu memang tidak selamanya baik. Meskipun demikian, pelaksanaan tradisi pernikahan kerubuhan gurung diserahkan kepada pelaku.

Secara jelas, tradisi kerubuhan gunung memang tidak terdapat dalam Islam. Tetapi pada dasarnya hal itu telah tersirat dalam ayat al-Qur'an, bahwa antar sesama kita harus peduli dan saling membantu. Jika seseorang sedang dalam keadaan bersusah, maka kita harus berempati. Jangan malah mengadakan pesta, apalagi sampai menghadirkan hiburan yang mahal. Itu akan jadi bahan pembicaraan lingkungan masyarakat awam seperti kita. Jika dipandang dari sudut sanksi yang diakibatkan, maka sejatinya pelanggaran pelaksanakan tradisi ini hanya mengakibatkan sanksi moral dalam masyarakat. Sudah tidak sedikit masyarakat yang terkena sanksi moral karena tidak melaksanakan tradisi ini, masyarakat menganggap bahwa orang seperti itu lebih mementingkan dirinya sendiri daripada harus sedikit menyalurkan kepeduliannya terhadap sesama. ${ }^{40}$

Hal ini diperkuat dengan pendapat RY yang menyatakan:

Kerubuhan gunung memang tradisi Jawa, kalaupun nggak dilaksanakan juga tidak apa-apa, tidak ada pengaruhnya. Sebagai seorang muslim, kok kesannya gimana gitu jika menikah berbarengan dengan keluarga yang meninggal dunia, kalaupun memang sudah meninggalk kita urus yang meninggal, kalau yang menikah ya diurus untuk menikah, keduanya tidak hubungannya. Masing-masing sudah ada tempatnya sendiri. Lebih baik jangan dicampur antara kesusahan dan kebahagiaan. Sudah, kalau ketika susah, ya susah, ketika bahagia ya monggo bahagia. $^{41}$

Penundaan perkawinan bisa dilakukan dalam jangka waktu yang singkat atau jangka waktu yang relatif lama, sesuai dengan kesepakatan keluarga. Menurut Qurthubi orang yang telah mampu dan takut pula akan merusak jiwanya dan agamanya harus berkeluarga. Apabila hasrat untuk menikah telah begitu mendesak, sedangkan biaya tidak ada atau dipandang kurang mencukupi, maka bulatkan saja pikiran untuk menikah, mudah-mudahan Allah memberi kelapangan. Bila tidak memungkinkan juga, disarankan memperbanyak puasa untuk mengurangi tekanan hawa nafsu. Jika seseorang dalam kondisi yang demikian, maka hukumnya wajib untuk segera melangsungkan sebuah perkawinan, dan haram untuk menundanya kembali. Diperkuat dengan terpenuhinya rukun perkawinan yang ada lima poin, yaitu adanya istri, suami, wali, dua orang saksi dan kalimat perkawinan (ijab qabul). ${ }^{42}$ Dalam pandangan masyarakt Jawa, tujuan perkawinan adalah pelaksanan tata susila dalam rangka pemuliaan akan turunnya

\footnotetext{
${ }^{39}$ Sholikhin, Ritual Dan Tradisi Islam Jawa, 180.

${ }^{40}$ AB, Wawancara (Malang, 2 Januari 2015)

${ }^{41}$ RY, Wawancara (Malang, 2 Januari 2015)

${ }^{42}$ Sholikhin, Ritual Dan Tradisi Islam Jawa, 187.
} 
ruh suci menjadi manusia. Tentunya dalam ikatan perkawinan haruslah ditanamkan rasa saling mengasihi dan menyayangi antara suami dan istri. Bukan karena penentuan hari yang salah, maka rasa tersebut tidak bisa ditumbuhkan dalam kehidupan rumah tangga. Bukan karena sejarahnya tidak pernah mengikuti omongan nenek moyang, menjadikan rumah tangga seseorang tidak diwarnai akan keharmonisan.

\section{Kesimpulan}

Berdasarkan uraian di atas dapat disimpulkan bahwa tradisi perkawinan kerubuhan gunung adalah tradisi yang hidup dalam kehidupan masyarakat Jawa di Kecamatan Kepanjen Kabupaten Malang dan telah diturunkan oleh para leluhur sejak dahulu. Tradisi ini tidak memperbolehkan seseorang untuk melangsungkan perkawinannya ketika terdapat keluarga dekat yang meninggal dunia. Penundaan dilakukan hingga tahun berikutnya. Bagi mereka yang melanggar tradisi ini diberikan sanksi sanksi moral dengan daya pengikat sedang. Misalnya cemoohan, gunjingan atau bahan pembicaraan. Para informan berbeda pendapat seputar keberlakuan tradisi ini. Kelompok berlatar belakang adat menilai bahwa warisan nenek moyang harus tetap dipegang teguh dan dilestarikan dari generasi ke generasi. Tradisi ini tidak boleh digantikan dengan tradisi yang lain. Sementara itu, kelompok berlatar belakang agama menilai bahwa masyarakat seyogyanya tidak melakukan tradisi ini sepenuhnya. Penghormatan terhadap tradisi bukan berarti membawa masyarakat pada hal-hal yang bersifat musyrik. Tokoh pemerintahan mengikuti apa yang menjadi pilihan dari pelaku dan tetap mengadakan perlindungan kepada mereka yang melakukan atau tidak melakukan tradisi kerubuhan gunung. Pelaksanaan tradisi berkaitan erat dengan kearifan lokal masyarakat setempat. Dalam tradisi kerubuhan gunung, meskipun ajaran Islam tidak mengatur pelaksanaan tradisi ini, ada makna tersirat yang dapat ditemukan yaitu mengekang menekan ego pribadi, saling menghormati, menghargai, dan menumbuhkan sikap toleransi antar sesama dengan ikut berduka atas kematian saudara dekatnya.

\section{Daftar Pustaka}

Adnan, Moh Mus'id. "Tradisi kawin boyong dalam perkawinan adat masyarakat Gesikan: Studi kasus di Desa Gesikan Kec.Grabagan Kab.Tuban.” Undergraduate, Universitas Islam Negeri Maulana Malik Ibrahim, 2008. http://etheses.uin-malang.ac.id/4226/.

Ahmadi, Abu. Ilmu Sosial Dasar. Jakarta: Bina Aksara, 1988.

Athiyah, Maullimatul. "Tradisi penyerahan perabot rumah tangga dalam perkawinan: Studi Kasus di Desa Karduluk Kec. Pragaan Kab. Sumenep Madura.” Undergraduate, Universitas Islam Negeri Maulana Malik Ibrahim Malang, 2010. http://etheses.uinmalang.ac.id/1457/.

Bawani, Imam. Tradisionalisme Dalam Pendidikan Islam: Studi Tentang Daya Tahan Pesantren Tradisional. Surabaya: Al-Ikhlas, 1993.

Emzir. Analisis Data: Metodologi Penelitian Kualitatif. Jakarta: RaJawali Pres, 2010.

Hasan, M. Ali. Pedoman Hidup Berumah Tangga Dalam Islam. Jakarta: Prenada Media Group, 2006.

Khalil, Ahmad. Islam Jawa: Sufisme Dalam Etika Dan Tradisi Jawa. Malang: UIN-Malang Press, 2008.

Mardalis. Metode Penelitian Suatu Pendekatan Proposal. Jakarta: Bumi Aksara, 1999.

Marzuki. Metodologi Riset. Yogyakarta: PT. Prasetia Widia Pratama, 2000.

Partanto, Pius A., and M. Dahlan Al Barry. Kamus Ilmiah Populer. Surabaya: Arloka, 1994.

Rodliyah, Siti. "Pandangan masyarakat terhadap tradisi ngelangkahi pasangan sapi dalam prosesi perkawinan di Desa Kepuh Kecamatan Papar Kabupaten Kediri." Undergraduate, Universitas Islam Negeri Maulana Malik Ibrahim, 2010. http://etheses.uin-malang.ac.id/1711/. 
Romlah, Siti. Karakteristik Keluarga Sakinah Dalam Perspektif Islam Dan Pendidikan Umum. Jakarta: UII Press, 2006.

Rufaida, Arini. "Tradisi begalan dalam perkawinan adat Banyumas perspektif 'urf." Undergraduate, Universitas Islam Negeri Maulana Malik Ibrahim, 2011. http://etheses.uin-malang.ac.id/1420/.

Sholikhin, Muhammad. Ritual Dan Tradisi Islam Jawa: Ritual-Ritual Dan Tradisi-Tradisi Tentang Kehamilan, Kelahiran, Pernikahan, Dan Kematian Dalam Kehidupan Sehari-Hari Masyarakat Islam Jawa. Yogyakarta: Narasi, 2010.

Soekanto, Soejono. Pengantar Penelitian Hukum. Jakarta: UI Press, 1986.

Suharti, Suharti. "Tradisi Kaboro Co'i pada perkawinan masyarakat bima perspektif urf di Kecamatan Monta Kabupaten Bima.” Undergraduate, Universitas Islam Negeri Maulana Malik Ibrahim, 2008. http://etheses.uin-malang.ac.id/4287/.

Sztompka, Piotr. Sosiologi Perubahan Sosial. Jakarta: Prenada Media Group, 2007.

Timoer, Soenarto. Mitos Çūra-Bhaya: Cerita Rakyat Sebagai Sumber Penelitian Sejarah Surabaya. Balai Pustaka, 1983. 